to New Zealand to observe the transit of Venus of 1874. While at the Antipodes he assisted the French to determine the longitude of the Campbell Islands. He returned to England in 1875, and three years later was sent to Hong Kong as chief engineer of the Admiralty works. While there he designed a physical observatory for astronomical, magnetical, meteorological and tidal observations, and he made exact determinations of the position of the Hong Kong Observatory at Mount Elgin, Kowloon. In 1882, on his way home, he prepared a scheme for waterworks for Yokohama. This had been done at the request of the Japanese Government, and in 1885 he returned to the East to superintend the work. He also designed works for Osaka and Hakodate. He retired from the British Army in 1887 with the rank of major-general and died at Tokyo on March 10, 1893, at the comparatively early age of fifty-four years.

\section{Research on Influenza}

THe Medical Research Council has published a long report of the investigations made by Dr. C. $H$. Andrewes and his colleagues into the influenza epidemic of 1936-37 (Medical Research Council, Special Report Series, No. 228. London : H.M. Stationery Office, 1938. 2s. 6d. net). They have amply confirmed their previous discovery that there is an acute disease which may be properly called 'influenza', due to a virus which is specially infective for ferrets, and that many outbreaks of a somewhat similar kind are not associated with the virus; these they call "febrile catarrhs". Much attention was given to the possibility of diagnosing the real influenza by clinical means, and with a certain amount of success, though it is clear that accurate differentiation without demonstration of the virus is still rather uncertain. They have also confirmed the disconcerting American finding that all strains of the virus are not antigenically the same. Their plans for large-scale trials of preventive inoculation were anticipated by the epidemic, which came earlier than was expected and made a muddle of the experiments; so far as they went, however, they did not show that inoculation was of any preventive value. Nor did the few cases which were treated with an anti-serum derive much benefit. In these respects, therefore, the results are disappointing, though a good deal has been done towards obtaining greater success in the outbreak which may be expected next winter.

\section{The Earthquake in Anatolia}

ON April 19, a destmuctive earthquake occurred in central Anatolia. Its epicentre lay near Kirshehir, about 90 miles south-east of Angora, and in this district ten villages were completely destroyed and at least 200 persons were killed. In Yozgad, about 60 miles north-east of Kirshehir, much damage was also caused, but the loss of life was small. The disturbed area extended from the Black Sea nearly to the Mediterranean. The first vibrations reached London at 12.11 p.m., and the earthquake must therefore have occurred shortly before 2.30 p.m., local time, when most of the inhabitants were at work in the fields. Since the beginning of the eighteenth century, not less than thirty-one great destructive earthquakes (of intensity 3, Milne scale) have occurred in Turkey in Asia, with one exception either in the west of the country about Smyrna and Broussa or in the east about Erzeroum and Diarbekr. The central portion of the country has been comparatively undisturbed. From Miss Bellamy's "Catalogue of Earthquake Epicentres" we find that during the years 1913-30 there were six earthquakes in three centres near Kirshehir and Yozgad, though none was strong enough to be recorded more than $80^{\circ}$ from the origin. In 1902, however, there was a destructive earthquake at Kastamonu, about 150 miles north of Kirshehir, of about the same intensity (degree 3) as the recent earthquake.

\section{The Magnetic Storm of April 16}

IN the note on the great magnetic disturbance of April 16 as recorded at Abinger Observatory, printed in Nature of April 23, p. 721, it was only possible to give tentative estimates of the range in declination and horizontal intensity, for reasons then stated. Critical examination of the traces has since been made which confirms the estimate for declination but considerably reduces the figure given for horizontal intensity. The definitive ranges in the three elements are now stated, with the times of maximum and minimum, as below :

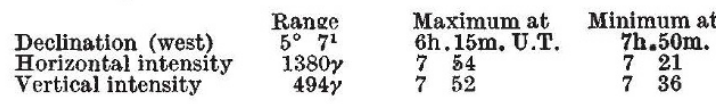

\section{York Museum of "Bygones"}

The Castle Museum, York, of which the nucleus is the collection of Yorkshire "Bygones" formed by Dr. J. L. Kirk, of Pickering, was formally declared open by Lord Middleton, lord lieutenant of the East Riding, on April 23. The Museum is housed in the eightoenth century buildings, formerly the female prison, of York Castle, which, with the exception of the medieval Clifford's Tower, vested in H.M. Commissioners of Works under the Ancient Monuments Acts, is now in the possession and under the control of the Corporation of the City of York. The Corporation will be responsible for the maintenance of the Museum, and the sum of $£ 8,000$, in addition to two grants of $£ 500$ each from the Carnegie Trustees and the Rowntree Trustees, has been expended on the installation. The exhibits, including a Tudor half-timbered house and fifteen shop-fronts in two and three storied houses flanking a cobbled street, illustrate the life, domestic, commercial and industrial, of Yorkshire over a period of two centuries ending with mid-Victorian times. Among the more striking and characteristic features are old hearths and their furniture and old agricultural implements and horsebrasses. By a judicious arrangement with the former owner, the Corporation has retained the right to enlarge the collection with the view of making the exhibits illustrate as fully as possible the oldtime life of the folk of Yorkshire. An annexe, for example, is to be added shortly, which will house specimens of old and obsolete vehicles. As was pointed out at the opening ceremony by Dr. Mortimer Wheeler, 